\title{
A STUDY ON INDONESIAN TEACHERS' USE OF TECHNOLOGY IN ENGLISH LANGUAGE TEACHING
}

\author{
Isry Laila Syathroh ${ }^{1}$, Bachrudin Musthafa ${ }^{2}$, Pupung Purnawarman ${ }^{3}$ \\ 1,2,3 Universitas Pendidikan Indonesia \\ 1islaisya@yahoo.com, ${ }^{2}$ din_musthafa@yahoo.com, ${ }^{3}$ p_purnawarman@yahoo.com
}

\begin{abstract}
Since 1960, technology has been used as one of educational tools to help teachers in teaching learning process. In the context of foreign language teaching, technology is utilized for various reasons and purposes. A questionnaire was distributed to 150 English as foreign Language (EFL) teachers in West Java to investigate the use of technology in their EFL classroom. Specifically, this paper reports the type of technology which teachers usually use in teaching English and also elaborate the reasons why teachers apply technology in their classrooms. Finally, this paper explores teachers' attitudes on the use of technology in language teaching.
\end{abstract}

Keywords: Technology, EFL classroom, EFL teachers

\begin{abstract}
Abstrak
Sejak tahun 1960, teknologi sudah mulai digunakan sebagai alat untuk membantu guru dalam proses belajar mengajar. Dalam konteks pembelajaran bahasa asing, teknologi digunakan untuk berbagai jenis alasan dan tujuan. Kuesioner didistribusikan kepada 150 orang guru Bahasa Inggris di Jawa Barat untuk menginvestigasi penggunaan teknologi di kelas mereka. Secara lebih spesifik, makalah ini menyajikan hasil survey mengenai teknologi yang dibiasa digunakan oleh guru Bahasa Inggris dan alasan mengapa guru menggunakan teknologi tersebut di dalam kelas. Di bagian akhir, makalah ini mneyajikan hasil survey mengenai attitude guru terhadap penggunaan teknologi dalam pengajaran Bahasa Inggris.
\end{abstract}

Kata Kunci: Teknologi, Kelas Bahasa Inggris, Guru Bahasa Inggris.

How to Cite: Syathroh, Isry Laila., Musthafa, Bachrudin., \& Purnawarman, Pupung. (2020). Study on Indonesian Teachers' Use of Technology in English Language Teaching. JEE, 3 (1), 01-12. 
2 Syathroh, Isry Laila., Musthafa, Bachrudin., \& Purnawarman, Pupung. (2020).Study on

Indonesian Teachers' Use of Technology in English Language Teaching.

\section{INTRODUCTION}

The use of technology is very popular today. Slowly but sure, technology has taken over many aspects of human life. In the aspect of education, the use of technology has been incorporated into teaching and learning process since 1960. Since technology has become the second nature of students nowadays, classical teaching and learning process will be very monotonous for them. Eliminating the use of technology in teaching and learning process would a way to alienate a critical part of the students' capabilities. Therefore, many teachers are challenged to use technology in their classes. Teachers are expected to integrate technology in language teaching to enhance learning.

This research is aimed at investigating the use of technology by English teachers in their EFL classroom. Specifically, two research questions are posed: 1) What types of technology do teachers usually use in teaching English?, 2) What are teachers' attitude towards the use of technology in teaching English? The two research questions become the central part of this research.

\section{Advantages of Using Technology in English Language Teaching}

The benefits of utilizing technology in language teaching has been studied by some scholars. The first advantage is related to students' learning motivation. Hennessy (2005) says that using technology can motivate students and teachers to work in new ways. Because of the new ways of learning, learners become more curious and autonomous, so teachers must support the learners to act and think independently. The next advantage of using technology in language teaching is the change of students' attitude and self-confidence. Gillespie (2006) and Costley (2014) also add that utilizing technology in language teaching can increase students' cooperation in learning materials. Another advantage of using technology in the classroom is easier classroom management. Teachers can present the materials interactively and students can get the course materials with fast access. (Rodinadze and Zarbazoia, 2012). The last advantage of technology in language teaching is the improvement of language learning (Baytak, Tarman and Ays, 2011).

\section{METHOD}

\section{Research Design}

This study was conducted in the framework of qualitative study approach. Crowl (1996) explains that qualitative research approach is used to examine questions that can best be answered by verbally describing how participants in a study perceive and interpret various aspect of their environment. By conducting qualitative research, researchers are given the opportunity to study social phenomena in relation to people's everyday lives. Through a process of data interpretation, qualitative research approach provides information about what, why and how a phenomenon in a society happens. In addition, Denzin \& Lincoln (2005) also claim that qualitative research approach also involves an interpretive, naturalistic approach to the world. Supporting this theory, Yin (1994) also elaborates that employing qualitative method provides researchers with opportunities to represent the views and perspectives of the people/participants in a study. The result of this study is then presented through descriptive analysis. According to McMillan and Schumacher (2001), a descriptive study asks what is or what was and it reports things the way they are or they were.

\section{Research Site \& Participants}

This research was conducted in West Java Province, Indonesia. Due to time constraints, the research site only covered three towns, namely: Cimahi, Bandung and Sumedang. About 150 participants were invited to join the survey via internet form, namely google form. However, only 123 filled out the questionnaire. Figure 1 below explains the profiles of participants, which cover their gender, age, affiliation, and length of teaching experience. 
Figure 1: Profiles of Participants

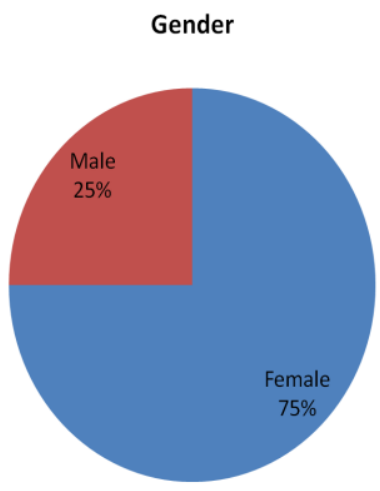

From the category of gender, figure 1 above shows that 31 people (25\%) of participant are male teachers, while 92 people (75\%) of participant are female English teachers. Then the range of age of participants is between 31 until 50 years old or more. Figure 2 below explains the description of age among participants:

Figure 2: Ages of Participants

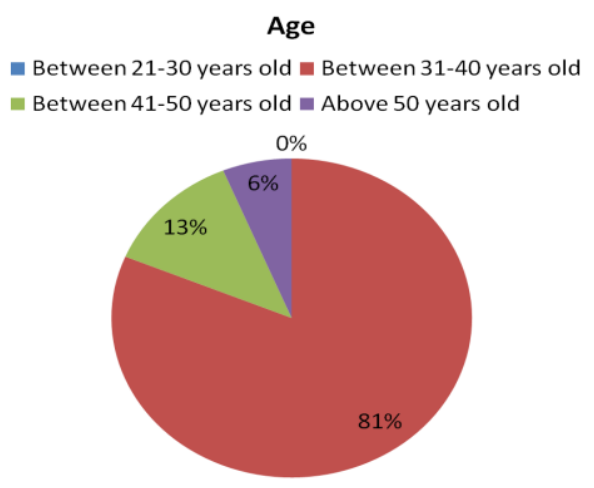

Figure 2 above shows that $6 \%$ ( 8 people) of participants are above 50 years old, $13 \%$ of participants (16 people) are between $41-50$ years old, and the majority of participants $(81 \%)$ or 99 people are between 31-40 years old. The participants involved in this research are from six kinds of affiliations, they are elementary school, junior high school, diploma, polytechnic and university level. The profiles are explained in the figure 3 below:

Figure 3: Affiliations of Participant

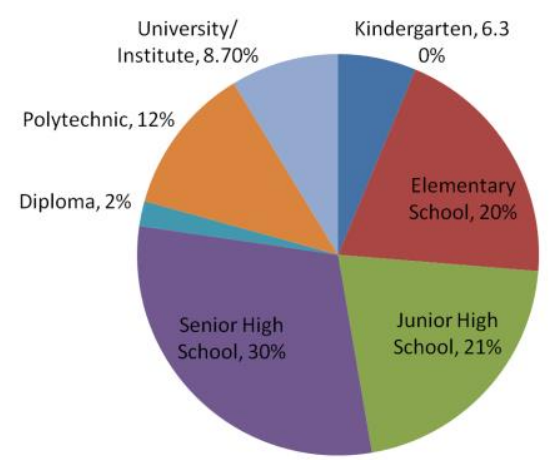


4 Syathroh, Isry Laila., Musthafa, Bachrudin., \& Purnawarman, Pupung. (2020).Study on Indonesian Teachers' Use of Technology in English Language Teaching.

Figure 3 above shows that 20\% (25 people) of participants are elementary school teachers, $21 \%$ (26 people) are junior high school teachers, 30\% (37 people) are senior high school teachers, $2 \%$ (3 people) are diploma lecturers, 12\% (15\%) are polytechnic teachers, and 8,7\% (11 people) are university lecturers. Then, the participants have different length of teaching experience which is described by figure 4 below:

Figure 4: Participants' Length of Experience

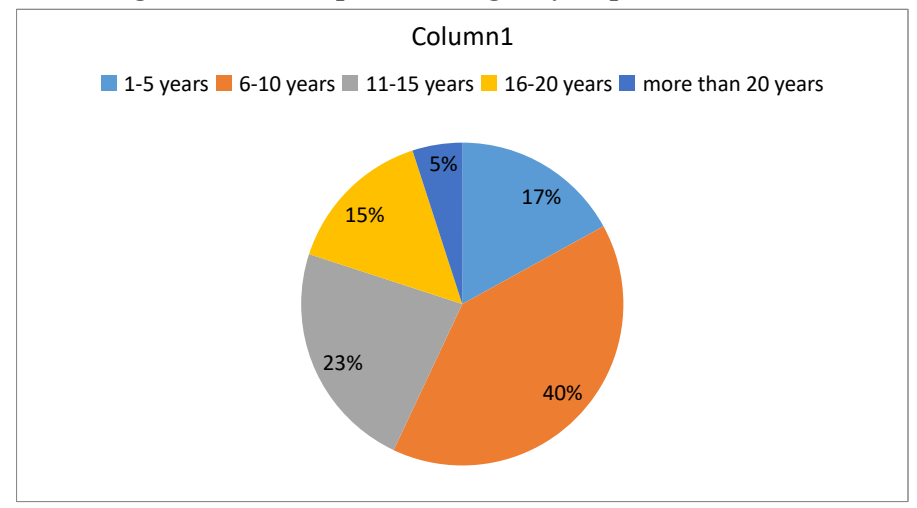

Figure 4 above shows that $17 \%$ (21 people) of participant have 1-5 years of teaching experience, $40 \%$ (50 people) of participant have 6-10 years of experience, $23 \%$ (29 people) have 11-15 years of teaching experience, $15 \%$ (19 people) of participant have 16-20 years of teaching experience and 5\% (4 people) of participants have more than 20 years of teaching experience.

\section{Instrumentation}

In conducting this research, the researchers used questionnaire to gain the data. About 150 teachers in Cimahi, Bandung and Sumedang were invited to fill out the questionnaire about the use of technology in EFL classrooms. However, among 150 invited participants, only 123 participants filled out the questionnaire.

Brown (2001) defines questionnaire as any written instruments that present respondents with a series of questions or statements to which they are to react either by writing out their answers or selecting from among existing answers. The researchers consider the questionnaire as one of the most appropriate techniques to elicit information about the use of technology in EFL classroom. Questionnaire can also be used to investigate teachers' attitudes toward the use of technology in language teaching. This is because questionnaire can measure attitudinal information by asking attitudinal questions. Dornyei (2009) elaborates that attitudinal questions are used to find out what people think. This is a broad category that concern attitudes, opinions, beliefs, interests and values.

The use of questionnaire as the instrument in this research has two advantages. The first issue is costeffectiveness. Questionnaire can save researchers' time, effort and financial resources. By administering online questionnaire to 150 teachers, a huge amount of information about the use of technology in their EFL classroom could be collected in a relatively short time. The second issue is versatility. According to Dornyei (2009), a questionnaire can be used successfully with a variety of people in a variety of situations targeting a variety of topics. Bryman (2008) also adds that a wellconstructed questionnaire can reduce the bias of interviewer effects and thus increase the consistency and reliability of the results. Due to these merits, it is no wonder that many research projects in social sciences employ questionnaire as one of the data collection techniques. The questionnaire was divided into three parts: 1) profiles of participant, 2) types of technology used in EFL classes, 3) purposes of using technology in EFL classes, and 4) teachers' attitudes towards the use of technology in EFL classes. 


\section{Research Procedure}

The first process in the research procedure was collecting the data. The data were collected by distributing online questionnaire via Google Form to 150 English teachers in Cimahi, Bandung and Sumedang. The invitation link to the questionnaire was distributed via Whattsapp Groups. However, among 150 invited participants, only 123 participants filled out the questionnaire.

The second process after collecting the data is analyzing the data. Burns (2000) explains that the purpose of analyzing the research data is to find meaning in the data by systematically arranging and presenting the information. It has to be organized so that comparisons, contrasts, and insights can be made and demonstrated.

Specifically, thematic analysis was used in analyzing the data. According to Boyatzis (1998) thematic analysis is a strategy in qualitative research to analyze information in a systematic way in order to make the data understandable. It organizes and describes the data in detail according to emergent themes found. In doing thematic analysis, the researchers utilized the six phases of data analysis by Braun and Clarke (2006) as the guidance. Table 1 below displays the six phases of thematic analysis process:

Table 1: Phases of thematic analysis (Braun and Clark)

\begin{tabular}{|c|c|c|}
\hline NO & PHASES & DESCRIPTION \\
\hline 1 & $\begin{array}{l}\text { Familiarizing with } \\
\text { the data }\end{array}$ & Transcribing data, reading and re-reading the data, noting down initial ideas \\
\hline 2 & $\begin{array}{l}\text { Generating initial } \\
\text { codes }\end{array}$ & $\begin{array}{l}\text { Coding interesting features of the data in a systematic fashion across the entire } \\
\text { data set, collating data relevant to each code }\end{array}$ \\
\hline 3 & $\begin{array}{l}\text { Searching for } \\
\text { themes }\end{array}$ & $\begin{array}{c}\text { Collating codes into potential themes, gathering all data relevant to each potential } \\
\text { theme }\end{array}$ \\
\hline 4 & Reviewing themes & $\begin{array}{l}\text { Checking the themes work in relation to the coded extracts (level 1) and the } \\
\text { entire data set (level 2), generating a thematic 'map' of the analysis }\end{array}$ \\
\hline 5 & $\begin{array}{l}\text { Defining and } \\
\text { naming themes }\end{array}$ & $\begin{array}{l}\text { Ongoing analysis to refine the specifics of each theme, and overall story the } \\
\text { analysis tells, generating clear definitions and names for each theme }\end{array}$ \\
\hline 6 & $\begin{array}{l}\text { Producing the } \\
\text { report }\end{array}$ & $\begin{array}{l}\text { The final opportunity for analysis. Selection of vivid, compelling extract } \\
\text { examples, final analysis of selected extracts, relating back of the analysis to the } \\
\text { research questions and literature, producing a scholarly report of the analysis. }\end{array}$ \\
\hline
\end{tabular}

As can be seen from table 1, the first step in the process of data analysis was organizing the data. This step covered transcribing the data gained from online questionnaire. The data then were analyzed and interpreted to identify the links between the data in every item in the questionnaire. After transcribing and translating the data, the next step was labeling the data based on the data sources. The next analytic procedure was repeatedly reading of the text of the transcription of the questionnaire. Afterwards, the next step in data analysis was coding. According to Creswell (2009), coding process is to make sense out of data, divide it into text or image segment, label the segments with codes, examine codes for overlap and redundancy and collapse these codes into broad themes. In this study, coding was intended to identify certain ideas in the data that represented the same meanings. And the final step is categorizing the data into the aspects related to the research questions posed. 
6 Syathroh, Isry Laila., Musthafa, Bachrudin., \& Purnawarman, Pupung. (2020).Study on Indonesian Teachers' Use of Technology in English Language Teaching.

\section{RESULTS AND DISCUSSION}

\section{Research Question 1: "What types of technology do teachers usually use in teching English?”}

The first part of the online questionnaire deals with the type of technology that English usually use in teaching English. The result of the questionnaire can be seen in figure 4 below:

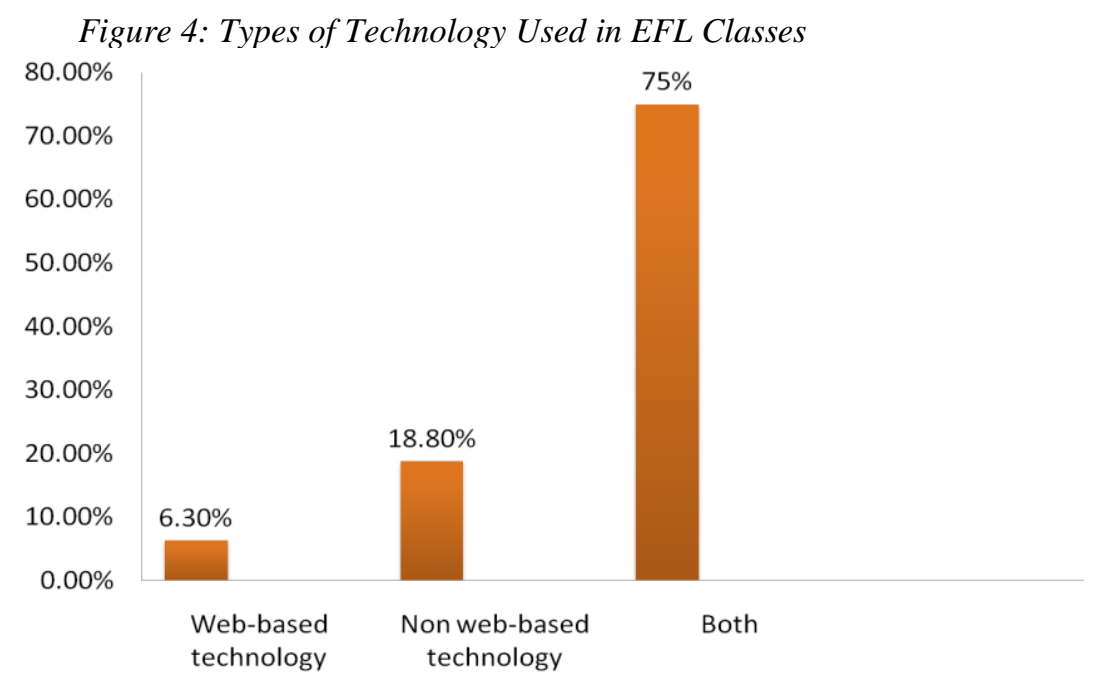

From the figure 4 , it can be inferred that $6,2 \%$ ( 8 people) of the participants usually use only webbased technology. While $18,8 \%$ of participants (24 people) usually use only non web-based technology, and 75\% (91 people) of participants use both web-based and non web-based technology. The next part of the questionnaire investigate types of non web-based technology used by the participants in their EFL classroom. Figure 5 below describes the answers from the participants of the research:

Figure 5: Types of Non Web-Based Tech

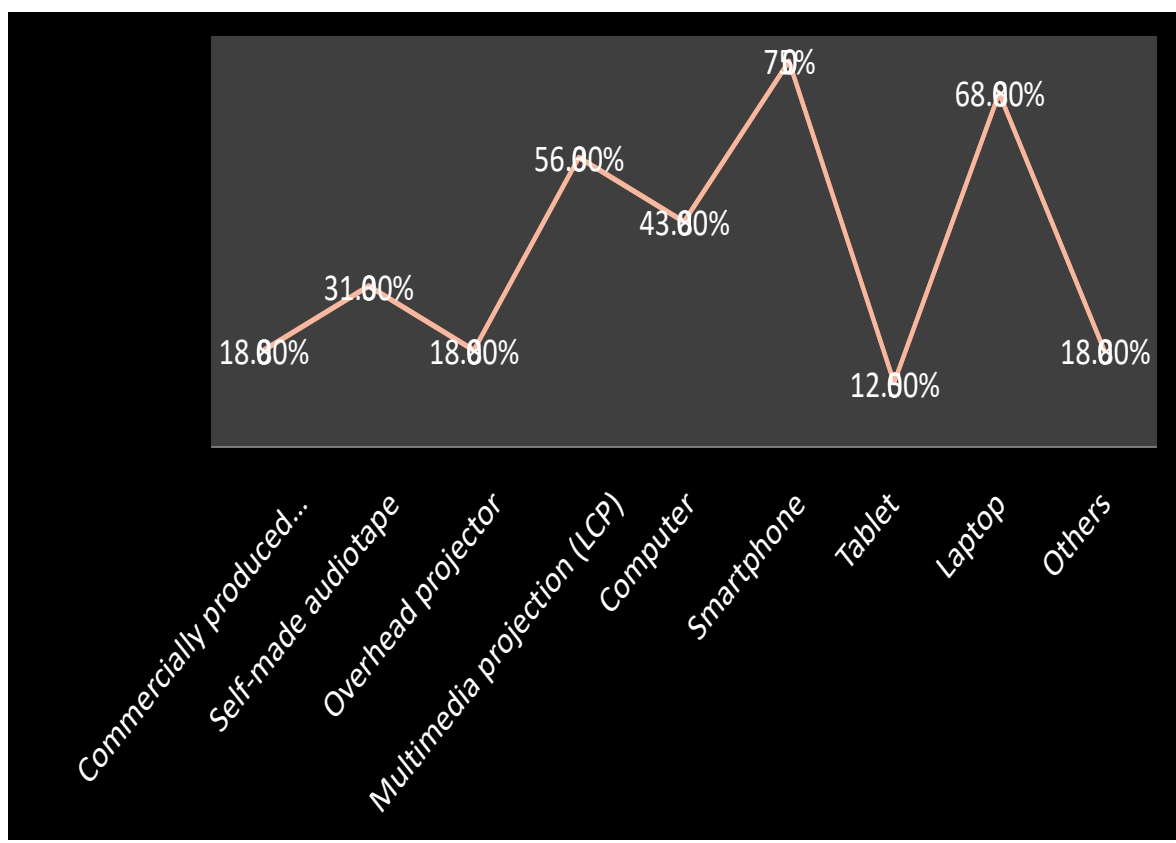


Figure 5 above shows that $18,8 \%$ ( 24 people) participants use commercially produced audio, $31,8 \%$ (40 people) use self-made audio, $18,8 \%$ (24 people) use overhead projector, $56,8 \%$ (70 people) use multimedia projection, 43,8\% (54 people) of participants use computer, $70 \%$ (86 people) of participants use smartphone, $12,8 \%$ (16 people) of participants use tablet, 68,8\% (85 people) of participants use laptop and 18\% (23 pople) of participants use other types of non web-based technology. The next question in the survey deals with the investigation about the use of web-based technology used by the participants of the research in their EFL classroom. Figure 6 below shows the result of the survey:

Figure 6: Types of Web-Based Tech

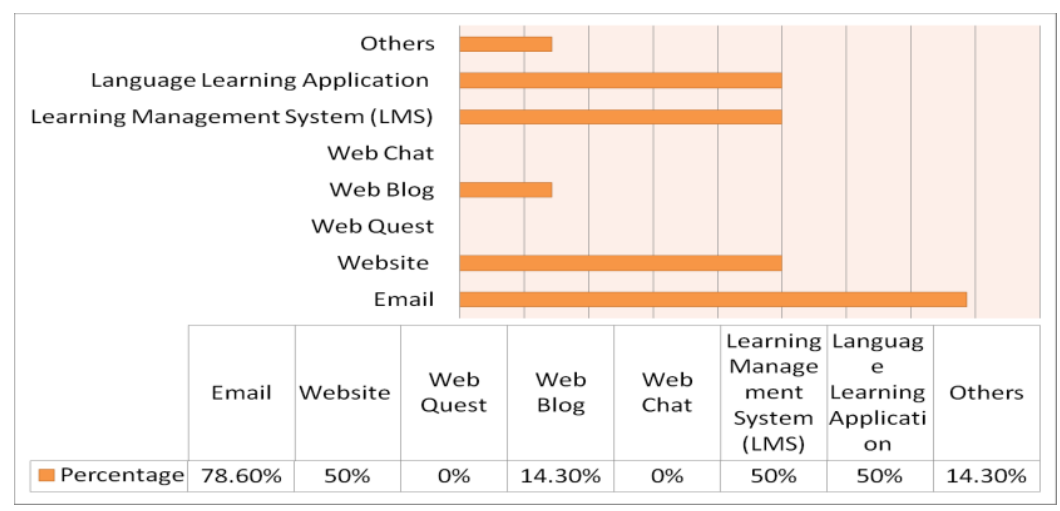

Figure 6 above shows that 78,6\% (97 people) of participants usually use email, 50\% (62 people) of participants use website, 14,3\% (18 people) of participants use web blog, 50\% (62 people) of participants use Learning Management System (LMS), 50\% (62 people) of participants use language learning application, and 14,3\% (18 people) of participants use others non web-based technology. The next part of the survey investigates types of technology, either web-based or non web-based, which are usually used by participants in their EFL classes. Table 2 below shows the answers from the participants:

Table 2: Types of Web-Based \& Non Web-Based Technology

\begin{tabular}{|c|c|}
\hline Web Based Technology & Non Web-Based Technology \\
\hline Google Classroom & Self made audiotape $(\mathrm{CD})$ \\
Kahoot & LCD projector \\
Padlet & Infocus \\
Google Classroom & Laptop \\
\hline https://onlineteachersuk.com/english- \\
homophones/ \\
Website / blog \\
Youtube & Video \\
\hline
\end{tabular}

The next part of the survey investigates the reasons why participants use technology in their EFL classroom. They show various answers to this question, and described in the following figure: 
8 Syathroh, Isry Laila., Musthafa, Bachrudin., \& Purnawarman, Pupung. (2020).Study on Indonesian Teachers' Use of Technology in English Language Teaching.

Figure 7: Reasons for Using Technology in EFL Classroom

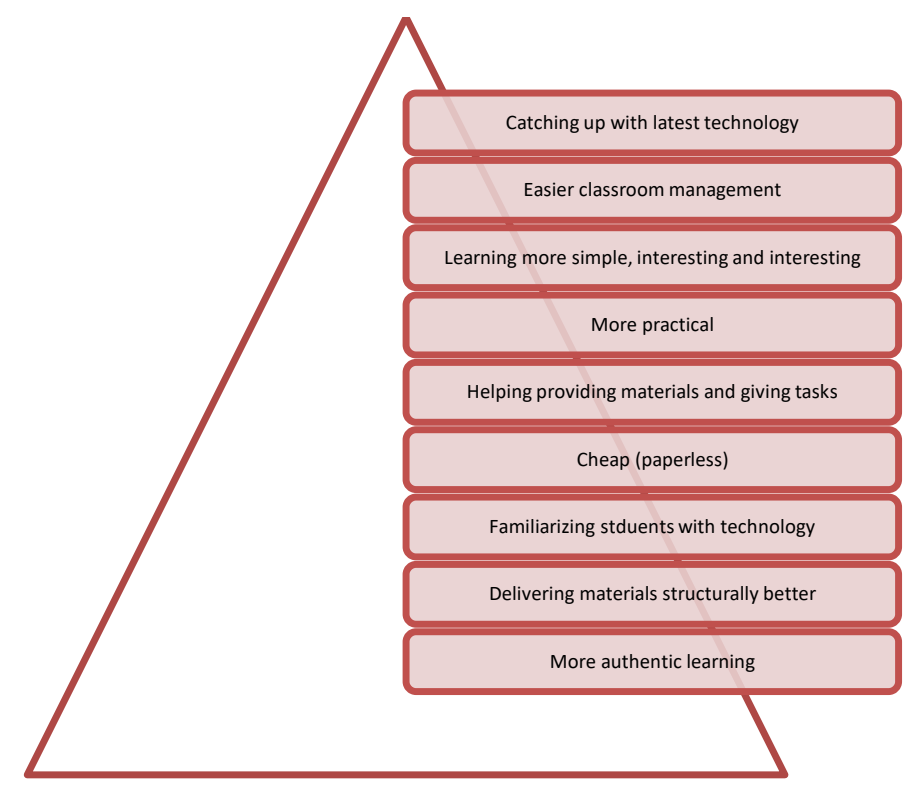

The next question investigates the students' responses to the utilization of technology in their EFL classrooms. The students gave various responses. Figure 8 below shows their responses:

Figure 8: Students' Responses to the Use of Technology in EFL Classes

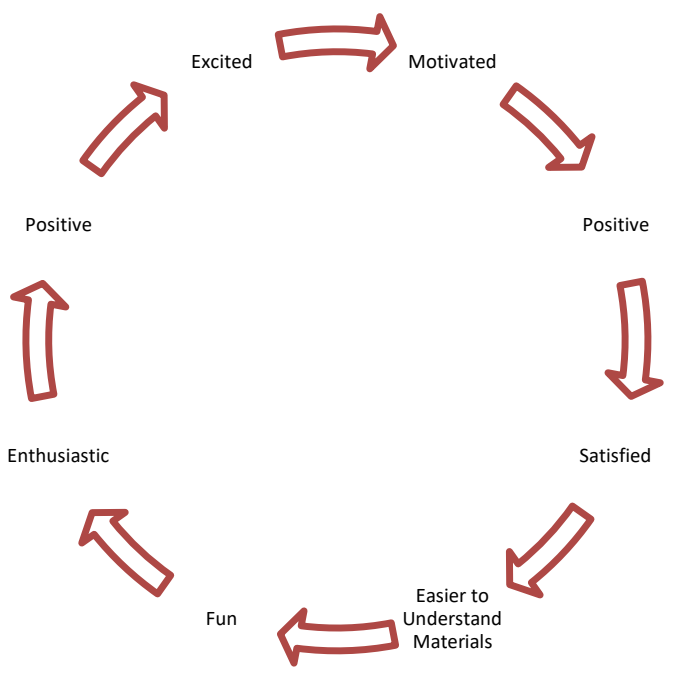

The next question explores whether technology affects students' achievement in English subject. Teachers show various answers, however all answers are categorized into positive answers regarding the use of technology in the EFL classroom. Some teachers say that technology has successfully increase students' motivation to learn English. Some teachers also say that technology is not particularly improving in students' scores English. In other words, by using technology, studnets' achievement is not increasing significantly. However, based on their observation, at least, technology can make teachers' work faster because students can grasp the materials better and they become independent learners.

Research Question 2: “What are teachers' attitudes towards the use of technology in teaching English?" 
The second section of the strvey investigates teachers' attitude on the use of technology when teaching English. Question 1 deals with their opinions whether English teachers should always use various types of technology in their classroom. Figure 9 below shows the result:

Figure 9: English teachers should always use various types of technology in their classrooms.

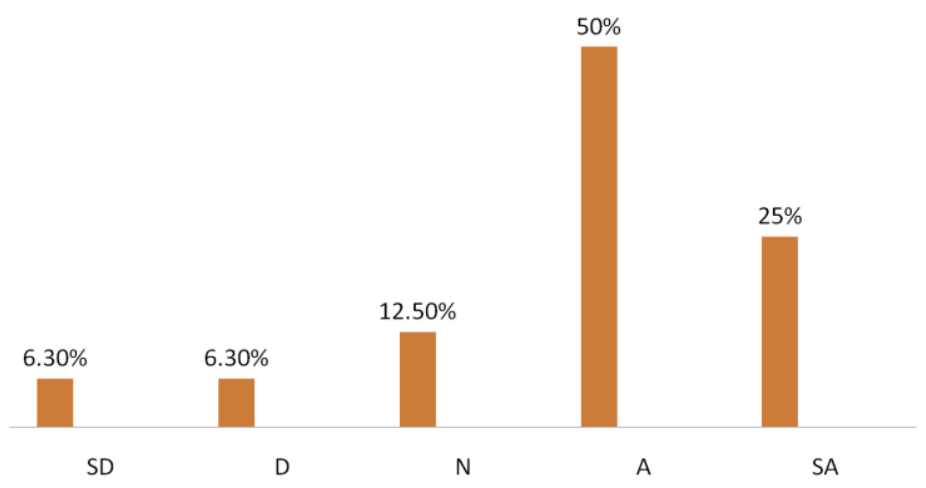

Figure 9 above shows that the majority of teachers (50\% or 62 people) agree that teachers should always use different types of technology in teaching English. Other teachers (25\% or 31 people) agree too. However, about $12,6 \%$ (16 people) of teachers disagree if they should always use technology in teaching English, since there are several things to be considered when teachers want to use technology in the classroom, such as: the availability of facilities, the suitability of materials, time availability, etc. The next aspect which is investigated in the survey is about teachers' opinion that students will learn better if they use technology in the class. Participants show various answers which are described in the following figure:

Figure 10: Students will learn better if they use technology in their classrooms

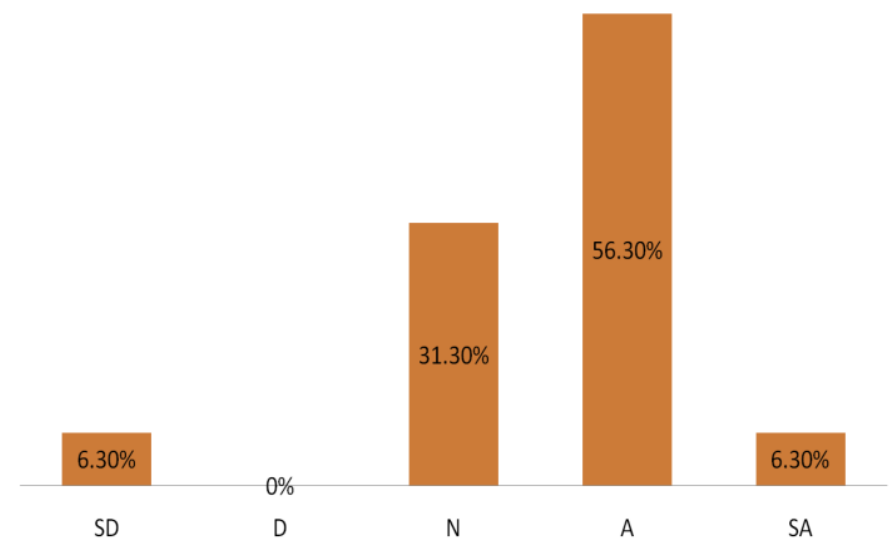

From figure 10 above, it can be concluded that majority of teachers (56\% or 70 people) agree if the use of technology can make teaching learning process better. They said that with technology can make teachers' work done faster. Classes are also easier to be managed, like scoring, task submission, attendance, etc. However, about $6,3 \%$ or 8 participants think that not all students are technology savvy, therefore using technology in the classroom will not guarantee sucessful teaching and learning process. Teachers have to make sure that students are to use technology in the class. The next aspect of the survey deals with teachers' opinion whether teaching language components like grammar, vocabulary, and pronunciation will be more effective by using technology. Answers from participants can be seen clearly in figure 11 below: 
10 Syathroh, Isry Laila., Musthafa, Bachrudin., \& Purnawarman, Pupung. (2020).Study on Indonesian Teachers' Use of Technology in English Language Teaching.

Figure 11: Teaching Language Components (grammar, vocabulary and pronunciation) will be more effective with the use of technology

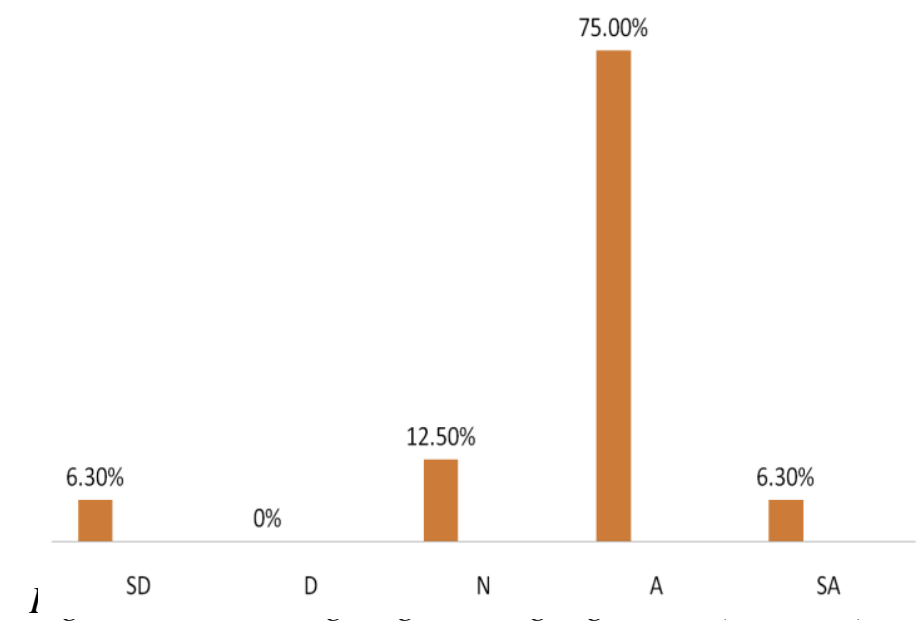

Figure 11 above shows that majority of teachers ( $75 \%$ or 93 people) think that teaching language components such as grammar, vocabulary, and pronunciation will be more effective by using technology. They said that there are many types of technology which can be used for teaching English, for example CD audio for teaching listening, Orai application for teaching pronunciation, grammarly for teaching grammar and so on.

\section{CONCLUSION}

From the discussion above, it can be concluded that the two research questions have been answered. There are two points to be concluded. Firstly, teachers have utilized different kinds of technology in teaching English, either web-based and non web-based technology. Teachers claim that the use of technology in language teaching can make teaching and learning process more effective, for example: easier classroom management, increased students' learning motivation, enhanching students' learning autonomy, improving students' scores, etc. Secondly, teachers show positive attitudes towards the use of technology in the classroom. They think that teaching language skills (listening, speaking, reading and writing) as well as teaching language components (grammar, vocabulary, and pronunciation) will be more effective by using technology. There are some language learning applications which can be used when teaching English, such as Orai, Grammarly, etc to improve language learning process. 


\section{REFERENCES}

Baytak, A., Tarman, B., \& Ayas, C. (2011). Experiencing technology integration in education: children's perceptions. International Electronic Journal of Elementary Education, 3(2), 139-151. https://www.iejee.com/index.php/IEJEE/article/view/233

Boyatzis, R. E. (1998). Transforming qualitative information: Thematic analysis and code development. California: Sage Publication, Inc.

Braun, V. \& Clarke, V. (2006). Using thematic analysis in psychology. Qualitative Research in Psychology, 3(2), 77-101.

Bryman, A. (2008). Social research methods (3rd ed.). Oxford: Oxford University Press

Burns, R. B. (2000). Introduction to research methods (4th ed.). French Forest: Longman Group Limited.

Costley, K. C. (2014). The positive effects of technology on teaching and student learning. Arkansas Tech University.

Creswell, J. W. (2009). Research design: qualitative, quantitative and mixed method approach. $3^{\text {rd }}$ edition. Thousand Oaks, California: Sage.

Crowl, T.K. (1996) Fundamentals of education research. US: Brown and Benchmark Publisher.

Denzin, N.K., \& Lincoln, Y. . (2005). Introduction: The discipline and practice of qualitative research.

In Y. . Denzin, N.K., \& Lincoln (Ed.), The sage handbook of qualitative research (2nd ed.). Thousand Oaks, California: Sage Publication.

Dornyei, Z. (2009). Research methods in applied linguistics: Quantitative, qualitative and mixed methodologies. Oxford: Oxford University Press.

Gillespie, H. (2006). Unlocking learning and teaching with ICT: Identifying and overcoming barriers. London: David Fulton. https://trove.nla.gov.au/work/20064464

Hennessy, S. (2005). Emerging teacher strategies for supporting. Cambridge, UK: University of Cambridge.

McMillan, J. H and Schumacher, S. (2001). Research in education: A conceptual introduction. New York: Longman.

Rodinadze, S., \& Zarbazoia, K. (2012). The advantages of information technology in teaching English language. Frontiers of Language and Teaching, 3(5), 271-275.

Yin, R. K. (1994). Case study research design and methods. $2^{\text {nd }}$ edition. Thousand Oaks, California: Sage Publication 
12 Syathroh, Isry Laila., Musthafa, Bachrudin., \& Purnawarman, Pupung. (2020).Study on Indonesian Teachers' Use of Technology in English Language Teaching. 